\title{
Women differentials in fertility: The case of rural and urban educational development in Benue State, Nigeria
}

\author{
1Bridget Demekaa and ${ }_{2}$ Umbur Demekaa, $P h D$ \\ ${ }_{1}$ University of Mka Library, Benue State, Nigeria \\ ${ }_{2}$ University Library and Information Services, Benue State University, Makurdi, Nigeria \\ 2E-mail: udemekaa@yahoo.com
}

\begin{abstract}
This study relates women education to fertility in the Ihugh (rural) and Makurdi (urban) setting in Benue State. The general purpose of the study is to test whether women with substantial schooling do have lower fertility than those without schooling. The study reveals that there is fertility differential for rural and urban settings, and that schooling is an index of the differentials. The study presents its findings and puts forward some recommendations that can help the government to address the issue of women education, especially the girlchild education.
\end{abstract}

Keywords: Fertility, Differential in fertility, Educational development, Women education and Girl-child education, Rural and urban, Benue State, Nigeria

\section{Introduction}

In Nigeria, and particularly in Benue State, women are disadvantaged in formal education, although women marginalization in education is not limited to Nigeria. It is the situation in all under-developed nations of the world. According to Haggis (1995), Zajacova and Lawrence (2018), in the world today, one in every three adult females is illiterate. Haggis goes further to advance reasons for this situation. The reasons are basically religious, social and economic factors. The literate level of the female has serious negative consequences for women themselves and for the rearing of children in their families.

In an attempt to generalize, there appears to be direct relationship between literacy and fertility; women education and physical health (Vable, et al, 2018). This informed by the assumption that when women become literate, they choose to have fewer children. The illiterate ones also appear to bear more children than the literate ones. Kim (2010). Emphasized that it is unclear whether education increases women's access to new information or their ability to adopt new birth control technology.

The assumption might be hazard that there is high inverse relationship between educational developments has taken place (Akilaiya, 1997). Fertility seems to define in women. These assumptions are so stated since the relationship of educational and birth rate seems characterized by uneven needs. Any analysis of the trend also seems to indicate that educational advancement is significant in order to address fertility. A study on Nigeria investigated a universal primary education program that took place between 1976 and 1981, and found that it also influenced fertility behavior. Accordingly to Osili and Long (2008), women with an additional year of schooling had, on average, 0.26 fewer children before age 25 than they would otherwise have had. Both studies compared students from the same area before and after the education programs were introduced. Findings show innate differences in the preference for children between educated and uneducated women. However, they do not explain why 
Bridget Demekaa and Umbur Demekaa: Women differentials in fertility: The case of rural, urban and educational development in Benue, Nigeria

better-educated women have fewer children nor do they determine which mechanisms (associated with education) were involved.

In essence, educational advancement of women will reduce fertility, to a reasonable degree (Demekaa, 2010); Demekaa, 2013) considering the exorbitant cost of fertility treatment outside the purview of the state. Ajir, (2006) and Covington-Ward, et al (2018) Differentiated between rural and urban setting, economic, sociological, ethnic, racial, educational dimensions are always considered. The rural setting of the Nigerian population can be distinguished from the urban setting in terms of the volume of the non-agricultural occupations within the two settings (Olatunbosun, 1995). For example, all economic activities in rural setting are dependent upon massive exploitation of the land. The rural setting occupations centre on poultry, farming, fishing, forestry, food processing and animal husbandry. Benue women are involved in all of these occupations in the rural setting.

The rural settings are settlements within some cases, isolated compounds, hamlets, and the village with population of between 100 and 20,000 inhabitants (Ajir, 2006).

There are usually no recreational facilities. This may account for the high sexual relationship between couples in the rural settings. Urban settings have modern amenities. The urban setting is an example of modern settlement with advanced technology. At the urban setting, there is electricity and portable water. The road network is advanced and transportation is easy. Modern and highly literate women inhabit the urban setting. At the urban setting, educational advancement is relatively more rapid than the rural setting.

\section{Statement of the problem}

This study intends to relate women education to fertility in the Ihugh (rural) and Makurdi (urban) settings. The general purpose of the study is to test whether women with substantial schooling have lower fertility rate than those without schooling.

The relation of women education to differential fertility is looked at from two major points of view:

1. Difference in fertility between women of Ihugh (rural) and Makurdi (urban) settings.

2. The differentials in fertility associated with women with substantial schooling as compared to those with no schooling.

The study presents its findings and puts forward some recommendations that can help the government address the issue of women education and especially the girlchild education.

\section{Research questions}

Two research questions have been asked to guide this study. These are:

i. Are there differences in fertility between women of Ihugh (rural) and Makurdi (urban) settings?

ii. Are there differences in fertility between women with substantial schooling and those with no schooling?

\section{Research hypotheses}

The following null hypotheses have been formulated for testing:

i. There are no significant differences in fertility between women of Ihugh (rural) and Makurdi (urban) settings.

ii. There are no significant differences in fertility between women with substantial 
Bridget Demekaa and Umbur Demekaa: Women differentials in fertility: The case of rural, urban and educational development in Benue, Nigeria

schooling and those with no schooling.

\section{Methods}

The population of the study comprised all the women in Benue State Nigeria. Women from Makurdi (Local Government Area) represented urban women; and women from Ihugh (Vandeikya Local Government Area), represented rural women. This gave an approximate population size of 300 women.

There were 10 women sampled for the purpose of this study. There were 5 $(50 \%)$ of the women from Makurdi, which was used as urban setting. There were 5 (50\%) of the women drawn from Ihugh, representing the rural setting. According to Onwioduokit (2001), if the population of the study is a very large one, the researcher needs a sample of $5 \%$. Based on this, a sample size of $5 \%$ of the population was chosen for this.

In all, out of the sampled women, six had at least OND and above. There were also four women without any formal education.

An interview is considered best for this study because some of the respondents used for this study were illiterates. Subsequently, an interview schedule designed; "Women Education and Fertility Differential Interview (WEFDI)" was the instrument used for the study. It was made up of two sections.

Section A, which was biographical data, sought such information as qualification, marital status, number of children, place of abode, age range of respondents and age range of respondents' first child (if any).

Section B contains six questions with each item response having five likerttype scale options. The questions sought the opinion of women both at the Ihugh (rural) and Makurdi (urban) settings. It also sought the opinion of women in the area of literacy and fertility differentials between women with substantial schooling and those with no schooling. The representatives of the researcher interpreted the contents of the instrument to the women respondents who were not literate.

The interview schedule which structured on likert four-point scale has Strongly Agree (SA), Agree (A), Disagree (D) and Strongly Disagree (SD). The data for the study was generated from the respondents' rating of the extent of their agreement or disagreement in each of the positively worked items. Weightings were $4,3,2,1$ while the negatively worked items were scored in reverse $1,2,3,4$. The sample percentage frequency was used after weighing the agreement and disagreement responses. Both Strongly Agree and Strongly Disagree were also collapsed to disagree.

Descriptive statistics percentages and inferential statistics, the chi-square contingency table were used to analyse the data. The null hypotheses were tested for significance at the .05 level.

The researcher sought the help of experts in test, measurement and evaluation from Guidance and Counselling, Department of Educational Foundations in Benue State University, Makurdi in relation to validity of the instrument. The instrument was tested for internal consistency by the split half method. The reliability coefficient was 0.82 .

The data analysis that follows has been presented according to the specific questions and hypotheses. The data relevant to providing answers to the two research questions have been analysed as presented in Tables 1-4.

\section{Result and discussion}

This study is concerned with data preservation analysis interpretation and 
Bridget Demekaa and Umbur Demekaa: Women differentials in fertility: The case of rural, urban and educational development in Benue, Nigeria

discussion of findings. The results are presented and analysed based on the research questions raised and hypotheses formulated for the study.

Research question one: Are there difference in fertility between women of Ihugh (rural) and Makurdi (urban) settings?
Table 1 gives the analysis of responses of the respondents on fertility differential between women at Ihugh (rural) and Makurdi (urban) settings. The score corresponding to the agree options was 33 or $66 \%$ of the responses and 17 or $34 \%$ representing the disagree responses. The result shows that Ihugh (rural) setting women have higher birth rate than those at the Makurdi (urban) setting.

Table 1: Birth rate of rural and urban women

\begin{tabular}{lllll}
\hline Category & SA & A & D & SD \\
Rural & 5 & 2 & 2 & 1 \\
$\begin{array}{l}\text { Women } \\
\text { Urban }\end{array}$ & 1 & 1 & & \\
Women & & & 4 & 4 \\
\hline
\end{tabular}

\begin{tabular}{lll}
\hline Population & Agree & Disagree \\
\hline Responses & 33 & 17 \\
Percentage & 66 & 34 \\
\hline
\end{tabular}

Table 2: Difference in fertility between women with no schooling compared to those with substantial schooling

\begin{tabular}{lllll} 
Category & SA & A & D & SD \\
Rural women & 2 & 2 & 4 & 2 \\
Urban women & 4 & 2 & 3 & 1 \\
Rural women & 3 & 3 & 2 & 2 \\
Urban women & 1 & 2 & 4 & 3 \\
\hline \multicolumn{5}{l}{ Disagree } \\
\hline Population & Agree & 34 \\
Responses & 67 & 34 & \\
Percentage & 67 & \multicolumn{3}{|l}{34} \\
\hline
\end{tabular}

Research question two: are there difference in fertility between women with substantial schooling and those with no schooling?

Table 2 shows the difference in fertility between women with no schooling compared to those with substantial schooling. The responses of those who agreed attracted 67 scores or $67 \%$ and those who disagreed scored 33 or $33 \%$. This result indicated that there is difference between women with no schooling compared to those with substantial schooling.

\section{Test of hypotheses}

Ho 1: There are no significant differences in fertility between women of Ihugh (rural) and Makurdi (urban) settings.

Hypothesis 1 is tested with the data in Table 3. Table 3 rveals the calculated chisquare of 11.61 is greater than critical 
Bridget Demekaa and Umbur Demekaa: Women differentials in fertility: The case of rural, urban and educational development in Benue, Nigeria

value of 3.84 at $\mathrm{df}=1$. Therefore, the null hypothesis which states that there no significant difference in fertility between women of Ihugh (rural) and Makurdi (urban) settings is rejected. This implies that there is significant difference in fertility between women of Ihugh (rural) and Makurdi (urban) settings. This statement agrees with Demekaa (2010) and Demekaa (2013) who shows in his study that a significant difference in educational advancement of women will reduce fertility to a reasonable degree.

Ho2: There is no significant difference in fertility between women with substantial schooling and those with no schooling.
Hypothesis two is tested with the data in Table 4. The result in Table 4 reveals that the calculated chi-square value of 5.24, which is above the critical value of 3.84 at $\mathrm{df}=1$. Therefore, the null hypothesis which states that there is no significant difference in fertility between women with substantial schooling and those with no schooling stands rejected. This indicated that there is significant difference in fertility between the women with substantial schooling and those with low schooling. This result agrees with Ajir (2006) and Covington-Ward, et al (2018), who in their research supported this finding, that differentiate between rural and urban setting, economic, sociological, ethnic, racial, educational dimensions are always considered.

Table 3: Test of significant difference in fertility between women of Ihugh (rural) and Makurdi (urban) settings

\begin{tabular}{|c|c|c|c|c|c|c|}
\hline \multirow[t]{2}{*}{ Category } & \multicolumn{2}{|c|}{ Fertility rate } & \multirow[t]{2}{*}{ Total } & \multirow{2}{*}{$\begin{array}{l}X_{2} \text { calculated } \\
\text { value }\end{array}$} & \multirow{2}{*}{$\begin{array}{l}\text { X2critical } \\
\text { value }\end{array}$} & \multirow[t]{2}{*}{ Decision } \\
\hline & High & Low & & & & \\
\hline Makurdi & $7(12.54)$ & $12(6.46)$ & 19 & 11.61 & 3.84 & Rejected \\
\hline Ihugh & $26(20.46)$ & $5(10.54)$ & 31 & & & \\
\hline Total & 33 & 17 & 50 & & & \\
\hline
\end{tabular}

$*$ = Significant at .05 , df $1=3.84$

Table 4: Test of significant difference in fertility between women with substantial schooling and those with no schooling

\begin{tabular}{|c|c|c|c|c|c|c|}
\hline \multirow[t]{2}{*}{ Category } & \multicolumn{2}{|c|}{ Fertility rate } & \multirow[t]{2}{*}{ Total } & \multirow{2}{*}{$\begin{array}{l}\mathrm{X}_{2} \text { calculated } \\
\text { value }\end{array}$} & \multirow{2}{*}{$\begin{array}{l}\mathrm{X}_{2} \text { critical } \\
\text { value }\end{array}$} & \multirow[t]{2}{*}{ Decision } \\
\hline & High & Low & & & & \\
\hline $\begin{array}{l}\text { High literacy } \\
\text { level }\end{array}$ & $24(29.85)$ & $21(15.15)$ & 45 & 5.24 & 3.84 & Rejected \\
\hline $\begin{array}{l}\text { Low literacy } \\
\text { level }\end{array}$ & $43(37.15)$ & $13(18.850$ & 56 & & & \\
\hline Total & 67 & 34 & 101 & & & \\
\hline
\end{tabular}

\section{Implications}

Women education is very important in order to control population. The family planning policy to the government will fail in the absence of education for women. From the findings of this study, the lower the schooling of women, the higher the birth rate. This is so because such women with little or no schooling are exposed to sexual activity early in life and such women marry early.

In line with the findings of the study, the following recommendations would be immense assistance to the government in solving the problem of population explosion in Nigeria. 
Bridget Demekaa and Umbur Demekaa: Women differentials in fertility: The case of rural, urban and educational development in Benue, Nigeria

1. The Government should emphasize Ihugh (rural) setting development in order to resolve population dilemma.

2. Women education should be encouraged.

3. There should be massive provision of recreational facilities concerning childbearing. Men and women should be provided with alternative means of pleasure.

4. Women should be assisted and encouraged to pursue higher education in order to reduce birth rate in women.

\section{Conclusion}

Women-Education and Girl-Child Education will reduce fertility among women.

\section{References}

Ajir, I.W. (2006). Health seeking behaviour in rural community: Case study of Akwanga Community of Nasarawa State. The Bепие Valley Journal of Interdisciplinary Studies, 5.

Akilaiya, O. (1997).Women education and differential fertility. Paper presented at NAEMT Conference.

Covington-Ward Y, Agbemenu $\mathrm{K}$ \& Matambanadzo A. (2018). We feel like it was better back home: stress, coping, and health in a U.S. dwelling Afr Immigrant Commun 2018;29. Doi: https://doi.org/10.1353/hpu.2018.0 018.

Demekaa, U. (2010). The impact of qualification on legislators and their information utilization. International Journal of Librarian Science (IJLS) Special. Retrieved from www.ceser/com/cp.jour/www.ceser publication.

Demekaa, U. (2013). The influence of qualification on family planning and their information utilization: case of Makurdi local government area. Global Journal of Academic Research Forum (GLOJACARF) Vol.1 (2).

Haggis, M.S. (1995), The education for all teacher training package. UNESCO Documentation ED.95/WS/1, Paris/UNE SCO.

Kim, J. (2010). Women's education and fertility: An analysis of the relationship between education and birth spacing in Indonesia." Economic Development and Cultural Change 58:4: 739-774.

McCrary, J. \& H. Royer (2011). The effect of female education on fertility and infant health: Evidence from school entry policies using exact date of birth. American Economic Review, 101(1), 158-195.

Monstad, K., C. Propper, \& K. G. Salvanes (2008). Education and fertility: Evidence from a natural experiment. The Scandinavian Journal of Economics, 110(4) 827852.

Olatunbosun, D. (1995), Nigeria's neglected rural majority. Ibadan: Oxford University Press.

Onwioduokit, F.A. (2001), Educational methodology and statistics. Uyo: Dorand Springfield.

Osili, U. O. \& B. T. Long (2008). "Does female schooling reduce fertility? Evidence from Nigeria." Journal of Development Economics 87,1: 5775.

Pop-Eleches, C. (2010). The supply of birth control methods, education, and fertility. Journal of Human Resources, 45(4), 971-997. 
Bridget Demekaa and Umbur Demekaa: Women differentials in fertility: The case of rural, urban and educational development in Benue, Nigeria

Vable A, Kiang M, Basu S, Rudolph K, Kawachi I. \& Subramanian S. (2018). Military service, childhood socio-economic status, and late-life lung function: Korean war era military service associated with smaller disparities. Retrieved from https://doi.org/10.1093/milmed/usx 196.

Zajacova A. L. and Lawrence, E. M.
(2018). The relationship between education and health: Reducing disparities through a contextual approach. nnu Rev Public Health. 2018, 39: 273-289. Retrieved from https://www.ncbi.nlm.nih.gov/pmc/ articles/PMC5880718/pdf/nihms94 7038.pdf. doi:10.1146/annurevpublhealth-031816-044628. 